\title{
Good Living Goals. A proposal for the construction of a global trans- development ${ }^{2}$
}

To those who believe that another world is possible and, in particular, to those who strive to build it.

The welfare paradigm of trans-modern trans-development (Múnera, 2016; CubilloGuevara \& Hidalgo-Capitán, 2015; Hidalgo-Capitán \& Cubillo-Guevara, 2016) is that paradigm that pursues the satisfaction of the material and immaterial needs of society, through a participation process in which the people decides, under the principles of personal satisfaction, social equity and environmental sustainability, what are these needs and what means should be used to satisfy them. Under this paradigm, in which nature, society and the person occupy the centre of people's concerns, individuals feel part of different communities and part of nature and, as parts of a whole, defend harmonious coexistence between human beings and between them and nature.

This welfare paradigm corresponds to a cultural paradigm or worldview called transmodernity (Rodríguez-Magda, 2004), which we can define as a worldview based on intersubjective consensus that seeks consensual truths; that interprets all aspects of life to starting from the emotionally intelligent combination of postulates based

\footnotetext{
${ }^{1}$ Antonio Luis Hidalgo-Capitán is researcher in the Research Center on Contemporary Thought and Innovation for Social Development 'Transdisciplinary' Research Group, at the University of Huelva (Spain). Ana Patricia Cubillo-Guevara is researcher in the 'Transdisciplinary Research Group, at the University of Huelva (Spain).

2 This article was originally published in http://www.alternautas.net/blog/2019/12/12/good-livinggoals-a-proposal-for-the-construction-of-a-global-trans-development
} 
on faith, reason and imagination; and that pursuing the realization of the multiple expectations of different individuals through the participatory construction of agreed intercultural and socially and environmentally harmonious projects for the construction of a post-capitalist global society.

It is often asserted that trans-development, as welfare paradigm, is only feasible on a local scale, as is the case of eco-villages -e.g., the Findhorn eco-village in northern Scotland- or of some indigenous communities -e.g., the indigenous community of Sarayaku in the Ecuadorian Amazon- (Hidalgo-Capitán \& Cubillo-Guevara, 2016). In fact, it is also affirmed that the attempts to implement trans-development as a paradigm of welfare on a national scale in some Latin American countries have been a failure -'buen vivir' in Ecuador; 'vivir bien' in Bolivia; 'vivir bonito' in Nicaragua, and 'socialism of good living' in El Salvador- and that in reality these countries have continued to implement development policies that have deepened their level of maldevelopment.

Nevertheless, there are still some attempts and proposals that do not renounce that trans-development can have implementations beyond the local scope. Among them would be the proposal of an alternative global agenda to Sustainable Development Goals (SDGs), called Good Living Goals (GLGs). (Hidalgo-Capitán et al., 2018).

The proposal of an alternative global agenda to SDGs is the result of an investigation with the help of experts in good living, degrowth and trans-development, through international discussion groups and a survey of more than 100 experts -academics, researchers, consultants, cooperators and social activists-. This reflection has not been intended to destroy the institutional proposal of SDGs, but the intention to generate a collective consciousness in the academy, social movements and international cooperation actors, which allows to propose a new Post-2030 Agenda, based on some goals that were not even included in the 2030 Agenda.

In our case, we assume that the welfare paradigm to which the Post-2030 Agenda should aspire would be trans-modern trans-development, a trans-modern and transdevelopmentalist epistemological perspective that openly questions modernity -as a 
cultural paradigm-, questions development -as a modern welfare paradigm-, questions sustainable development -as a variant of modern alternative development, and proposes to go beyond these paradigms and variant, without denying them completely, but transcending them.

\section{General Goals for Global Good Living}

The general goals for global good living include: bio-centric sustainability, reflecting a harmony with all beings in nature; social equity, reflecting harmony among all human beings; and personal satisfaction, reflecting harmony with oneself.

Bio-centric sustainability suggests to stop the loss of ecosystem biodiversity, species biodiversity, and genetic biodiversity, while accommodating the human ecological footprint to planetary bio-capacity. This implies taking bio-centrism as our approach (Taylor, 1986; Gudynas, 2010); that is, that conception of the world that considers that: people and society are not outside of nature, but within it; nature is not an infinite source of natural and environmental resources, but it has clear biophysical limits that we cannot exceed; and nature, as a natural heritage, has certain values that are its own -intrinsic values- and that are independent of its economic utility, such as natural capital -exchange values and use values.

Social equity proposes to reduce the levels of inequality in capacities and opportunities of the world population -among countries, regions, rural and urban territories, ethnic groups, religious denominations, social classes, genders, sexual identities and people- along with similar reduction in levels of achieved social welfare inequality. We consider social equity, as a criterion of social justice (Thompson, 2016), implies giving different treatment to the different ones to compensate for the unequal social capacities and opportunities that people, social groups and territories possess to achieve welfare (Stewart et al., 2012), and the moderation of the different levels of social welfare reached by people, social groups and territories.

Personal satisfaction aims to increase the levels of satisfaction of people with their own lives, in whatever territorial context, mean while reducing the gap between the 
levels of satisfaction of the most satisfied and least satisfied people. Personal satisfaction with one's own life -also understood as vital satisfaction, subjective wellbeing or happiness- (Diener et al., 1999) can be understood as the extent to which a person considers that the results of well-being obtained at a given time in his life correspond with the expected goals.

These three general goals for good living on the global scale are interrelated, and all three must be simultaneously fulfilled if good living is to be achieved. Still, there exists a kind of hierarchy between these goals, since bio-centric sustainability can limit the means to achieving social equity, and both bio-centric sustainability and social equity can limit the means to achieving personal satisfaction. Therefore, realization

of global good living would have to take into consideration nature first, society second, and the individual person third, since the person is part of society, and societies is part of nature.

Achievement of the general GLGs would further require simultaneous achievement of the specific GLGs. These twenty-one specific good living goals, especially those directly related to any of the three harmonies, present strong interrelationships among themselves.

\section{Specific GLGs of harmony with all beings of nature}

Specific GLGs related to harmony with all beings of nature are: ecosystems care; sustainable economy; sustainable extraction; transitions for climate; rights of nature; circular economy; and optimal habitats.

The goal of ecosystem care proposes stop the deterioration of aquatic and terrestrial ecosystems at the local, regional, national, transnational, and global levels, and initiate recovery processes through restoration policies in a way that contributes to the future development of safe living environments. Under a bio-centric logic (Gudynas, 2010), in which all human beings form a biological community with other beings of nature, ecosystems are the environments in which our life develops; the life of all beings of nature. In addition, under a systemic logic, all ecosystems have 
important interdependence relationships with other ecosystems, so that the deterioration, for example, of local ecosystems, increases the fragility of regional, national, transnational and global ecosystems.

The goal of rights of nature pursues enact a Universal Declaration on the Rights of Nature and constitutionally recognize these rights and their mechanisms of protection within each country, so that the intrinsic values of nature will be taken into consideration. From a bio-centric logic (Taylor, 1986; Gudynas, 2010), nature can be understood as the interactive set of all living beings and their habitats, which as such can be interpreted as a living entity of a higher order, the biosphere, which has some intrinsic values that are alien to the immediate utility they may have for human beings. Therefore, it should be recognized that nature has rights (Acosta et al., 2011) that must be recognized internationally, through a Universal Declaration of the Rights of Nature, which together with the Universal Declaration of Human Rights, articulate a set of principles and legal norms that protect both human beings and other beings of nature.

The goal of circular economy intends optimize the scale of local habitats to take advantage of agglomeration economies and to avoid diseconomies of agglomeration, reducing pressure on the carrying capacity of local ecosystems. Circular economy (Ellen MacArthur Foundation, 2012, 2013, 2014) can be defined as that strategy that seeks to reduce both the input of materials and the output of waste in production processes -littering-, closing the economic and ecological loops or flows of resources, and generating efficient economic processes in ecological terms. This advocates extending the useful life of the products to delay as much as possible the generation of waste and the preferential use of biodegradable materials in the manufacture of consumer goods, so that they can return to nature by depleting their useful life without cause environmental damage.

Finally, the goal of optimal habitats seeks to optimize the scale of local habitats to take advantage of agglomeration economies and to avoid diseconomies of agglomeration, reducing pressure on the carrying capacity of local ecosystems. The human beings live in local communities, for which we have been transforming certain 
local ecosystems until they become ecosystems of modified landscapes; that is, in urban, rur-urban and rural habitats. Community life is economically more efficient because it allows human beings to take advantage of localization economies, derived from the use of social infrastructure -energy and water supplies, sanitation and waste management, communication channels, educational centers, health centers, security services, etc. However, when certain population density thresholds have been exceeded, social infrastructure collapses generating agglomeration diseconomies supply cuts, air pollution, traffic jams, classroom and hospital saturation, waiting lists, crime, etc.- (Fujita \& Thise, 2002). Therefore, we must resize our human habitats, favoring the concentration of dispersed populations in small and intermediate towns and cities, limiting their growth in size, and encouraging emigration from large cities to small and medium-sized towns and cities.

\section{Specific GLGs of harmony with all human beings}

Specific GLGs related to harmony with all human beings are: local production; food sovereignty; participatory and peaceful democracy; progressive taxation; alternative economies; markets regulation; and affirmative action.

The goal of local production proposes encourage the development of small-scale and

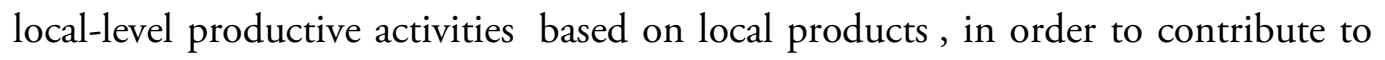
reducing poverty and social inequality levels within countries. Commuter products, or short value chains (Marsden et al., 2000; Kebir \& Torre, 2012), have among their virtues that, by requiring less transport, tend to generate less environmental impact and may even be cheaper. Likewise the consumption of these products also promotes local production destined for the local market with fewer intermediaries and smallscale. This generates networks of producers, consumers, businessmen and workers that energize local economies and contribute to reducing levels of poverty and social inequality đooth locally and nationally.

The goal of food sovereignty suggests implement productive and commercial policies with agro-ecological and cultural criteria to allow a transition toward food sovereignty for countries and local communities. The fight against hunger and overfeeding is not 
only a matter of provision and consumption of healthy food and in sufficient and adequate quantities to ensure adequate nutrition for people, but that such production must be based on ecological and cultural criteria. Therefore, food sovereignty (Foro Mundial por la Soberanía Alimentaria, 2001) -to which we must transit- implies that each country and each local community can define their own food, agricultural and land policies to ensure that they are healthy, nutritious, ecologically, socially, economically and culturally appropriate to your food needs. It is not only about guaranteeing a healthy and nutritious diet, but that it is culturally appropriate and at the same time strengthens the capacities of each society to support itself, without depending for its survival on transnational markets, on goodwill of the great economic powers or unpredictability and high costs of international transport (Rosset \& Martínez, 2014).

The goal of participatory and peaceful democracy aims to develop mechanisms of popular political participation and for the peaceful resolution of conflicts at the local, regional, national, international, and global levels, allowing transition to participatory and peaceful pluri-democracy adapted to each social context. Under a logic of participatory democracy (Fishkin, 2011) we must create mechanisms so that the plurality of people and social groups can participate in the political decisions that affect them (revocation referendums of mandates, popular consultations, legislative initiatives popular, participatory budgets, local popular assemblies, consensual decisions, etc.) and they feel more included and more easily respect the results of decision making while reducing social conflict.

The goal of progressive taxation invites to implement progressive taxation systems that redistribute the income generated in domestic markets, as well as mandatory commitments of official aid to good living between countries, to redistribute the income generated in international markets. The income distribution inequality \manating from both the performance of domestic markets and the performance of international markets $\bigotimes$ (Piketty, 2013) must be corrected for the sake of social equity and even the happiness of people (Oishi et al., 2012). This means that the fiscal

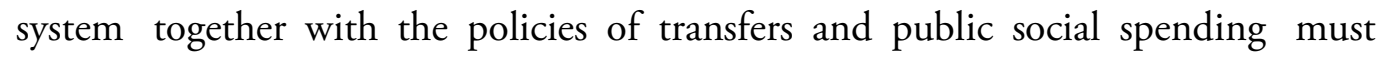


modify the distribution of income and make it more equitable (Wilkinson \& Pickett, 2009). Likewise in the international sphere the redistribution of income must be modified by means international cooperation (Brandt et al., 1980; Quilligan, 2002) with international protocols for official assistance for good living that fix $0.7 \%$ of the GDP of high-income countries as their minimum contributions to the financing of good living projects.

The goal of alternative economies pursues encourage satisfaction of the fundamental needs of people by means other than the market that generate a more equitable distribution of income and wealth. The market economy generates an unequal distribution of income and therefore of wealth (Piketty, 2013); then the generation of a more equitable distribution of income and wealth goes through alternative ways to market to meet the fundamental needs of people (Max-Neef, Elizalde \& Hopenhayn, 1986). Thus, alternative economies comprise the set of organizations, productive systems and consumption systems in which utilitarian rationality, profit and wealth accumulation does not prevail.

The goal of markets regulation intends regulate local, national, transnational, and global markets through local, national, and international public authorities, to avoid concentration of market power into the hands of a few actors. Free markets have a tendency to concentrate the power of markets in few hands by virtue of the continued growth in the size of companies in order to take advantage of economies of scale, leading to oligopolies and oligopsonies -when not monopoly and monopsonies- that almost always end up being collusive and damaging the interests of their numerous customers or suppliers with little market power (Dixon, 2001). And this trend is common to all market scales -local, national, transnational and global.

Finally, the goal of affirmative action seeks to implement, within countries, policies of affirmative action that increase the initial capabilities and opportunities of the most disadvantaged persons, along with economic and social policies of limitarianism to reduce the final income and welfare of the most favored people. Affirmative action policies (Stewart et al., 2012) would facilitate the path towards personal good living and contribute to social good living by reducing the levels of social inequality to 
different social groups -children, youth, elderly, women, queers, ethnic minorities, religious minorities, disabled, sick, illiterate, poor, etc. While social limitarianism policies (Robeyns, 2014) should be aimed at limiting the maximum levels of income and welfare that could be obtained by the most favored people -usually, but exclusively, men, middle-aged, heterosexual, ethnic majority and religious of the country, with full capacities, healthy, educated and rich. Social limitarianism may be the result of a personal ethic freely adopted by the most favored persons -corporate social responsibility, philanthropy, etc.-, but it may also be the result of public policies for the correction of differences -fiscal progressivity, partial expropriations of wealth, etc.-; in this way they would reduce their high levels of comfort, which in many cases do not lead to personal good living, and also contribute to social good living by reducing levels of social inequality.

\section{Specific GLGs of harmony with oneself}

Specific GLGs related to harmony with oneself are: interculturality; diverse identities; contextual education; simple life; spiritualities; pluri-nationality; and integral health.

The goal of interculturality proposes recognize, respect, and encourage the different ethnic identities and cultural practices within each country and between countries, as well as the right of cross-border mobility and the harmonious coexistence of different ethnic groups under criteria of interculturality, in order to contribute to the flowering of all cultures. The complex societies of all countries and many local communities are ethnically plural in their origins and this plurality is increasing as a consequence of migratory movements; and said cultural plurality is an important asset of its heritage. In this sense we must implement policies of decoloniality of power, knowledge and being within each country and each local community (Mignolo, 2007), so that existing cultural diversity is valued and interculturality is encouraged (Walsh, 2009). Interculturality must be understood as harmonic coexistence and even hybridization (García-Canclini, 1990) of the different cultures that exist in the same territory. 
The goal of diverse identities suggests recognize and respect the diverse and plural identities in terms of gender, sexual identity, ethnic type, and phenotype, and foster de-patriarchalized, de-heteronormalized, and de-colonized social relationships, in order to diminish social discrimination by reason of identity. All people have collective and simultaneous identities that allow us to identify with certain groups; the most common identities being those referring to gender and sex -on the one handand ethnicity and phenotype -on the other. These identities -depending on the power relationship established between the different social groups (Quijano, 2000)- are the basis of multiple social discriminations. Patriarchy, heteronormativity and coloniality are the foundations of such discriminations, so that the recognition and respect of different gender, sexual, ethnic and phenotypic identities goes through the depatriarchization, de-heteronormativization and de-coloniality of social relations (Paredes, 2010). Only then people can improve their levels of personal satisfaction by fully developing in harmony with their own identity; identity that must be chosen through self-identification and not imposed socially.

The goal of contextual education aims to recognize, respect, and encourage the various forms of literacy, learning, and education throughout life, depending on the specific capabilities of people and their social and environmental context, so that they can develop themselves as persons. Education is a key element for the full and satisfactory realization of people who must develop throughout their lives, since it allows them to adapt better to the different and changing environments in which they live and even transform those environments (Freire, 1968). However there is great uniformity -both in terms of content and teaching-learning methods- which is not always adequate. Therefore it is necessary to develop methods and content adapted to the diverse capacities and contexts of people allowing a true contextual education. This education must be carried out throughout life (Delors et al., 1996) and must be adapted to the diverse capacities of people to be truly inclusive (Warnok et al., 1978). In addition it is necessary to recognize, respect and promote alternative educational methods to the conventional ones, either the traditional ones of different cultures or those developed from alternative pedagogical perspectives (Holt, 2002). 
The goal of simple life invites to recognize, respect, and encourage plural styles of a simple life that allow people to satisfy their fundamental human needs in their different territorial contexts. One of the aspects that generate greater dissatisfaction with our own life is the gap between what we desire and what we obtain (Diener et al., 1999). Our unlimited desires are stimulated by publicity and the demonstration effect, so that we try to satisfy our anxieties -or false needs- instead of trying to satisfy our fundamental needs (Max-Neef, Elizalde \& Hopenhayn, 1986); and this causes us unhappiness. However if we opt for sobriety -or voluntary simplicity (Gortz, 1997, 2003)- bypassing our anxieties and focusing on satisfying our fundamental needs which may vary from one territorial context to another depending on environmental, historical and cultural aspects- then the aforementioned gap will be reduced by facilitating the achievement of higher levels of satisfaction with our own lives.

The goal of spiritualities pursues recognize and respect, under criteria of secularism, the various religious faiths and spiritual practices, as well as the non-denominational nature of people and their right to express their spirituality in the public and private spheres, without conditioning the religious and spiritual practices of other people, so that all may freely and fully develop their spirituality. Most people assume that their lives have a spiritual dimension that they need to develop in order to feel satisfied with themselves (Chaeyoon \& Putnam, 2010). In this sense the various religions of the world and non-religious spiritual practices -such as, for example, vitalism- allow people to satisfy an important part of their fundamental needs. However there are also agnostic and atheistic people who fully develop as people without having a spiritual dimension in their lives. Hence both -religious and spiritual people, such as agnostic and atheistic people- have the right to practice their own religious or spiritual traditions or their non-practice in the private and public spheres. In this sense all States must be secular and maintain neutrality regarding the beliefs of residents in different countries, recognizing and respecting the various existing religions and spiritualities and their practices without encouraging any of them (Savater, 2004).

The goal of pluri-nationality intends constitutionally recognize and respect the different nationalities and nations, whether existing within each country or jointly 
within several countries, as well as their capacity to self-manage certain political competences, in such a way as to increase levels of collective autonomy of all peoples. We must transit from the political organization of the nation-States to the political organization of the pluri-national States (Acosta et al., 2009; Lupien, 2011). Those territorial groups of people who identify themselves as a nation must have the right to be recognized as such in the constitutions of the different countries and that their differential facts are respected and protected within the country to which they belong. In addition they must have the right to manage autonomously \without the political interference of other nations $\rrbracket_{c e r t a i n}$ powers granted by the State of the country to which they belong as a result of a political consensus between the different nations that conform it. These competences should be able to be exercised jointly between all the parts of the same nation that for historical reasons are located on territories belonging to several countries, which would require agreements between the plurinational States of those countries to allow recognition and operation of interstate nations (Albó, 2011).

Finally, the goal of integral health seeks to recognize, respect, and encourage, under criteria of scientific-social effectiveness, the different forms of medicine, to contribute to improving in each territorial context the holistic health of the people. The integral health of people -physical, psychic, emotional, spiritual and social health- is one of the elements that most influences the levels of satisfaction with their own lives, since people who are not healthy are usually relatively unsatisfied. Alongside conventional scientific medicine there are other forms of traditional and complementary medicine (WHO, 2013) -more economical, more holistic, more preventive, more community, more rudimentary and more based on natural remedies- which have high levels of social effectiveness and that allow improvements in people's health. These types of traditional and complementary medicine -such as traditional Chinese medicine, Indian ayurveda, European yunani, indigenous medicine, anthroposophical medicine, naturopathy, chiropractic, osteopathy and homeopathy (WHO 2013)- can be a complement -if not an alternative- to conventional scientific medicine to improve the health of people where it does not reach due to proximity, price or effectiveness. 


\section{Synthesis}

The GLGs consist of a set of twenty-four goals, three of them general and twentyone specific, aimed at achieving the three harmonious states -personal, social and environmental- that would likewise characterize global good living or global transdevelopment. Figure 1 illustrates the systemic articulation of all twenty-four goals.

\section{Figure 1. Good Living Goals}

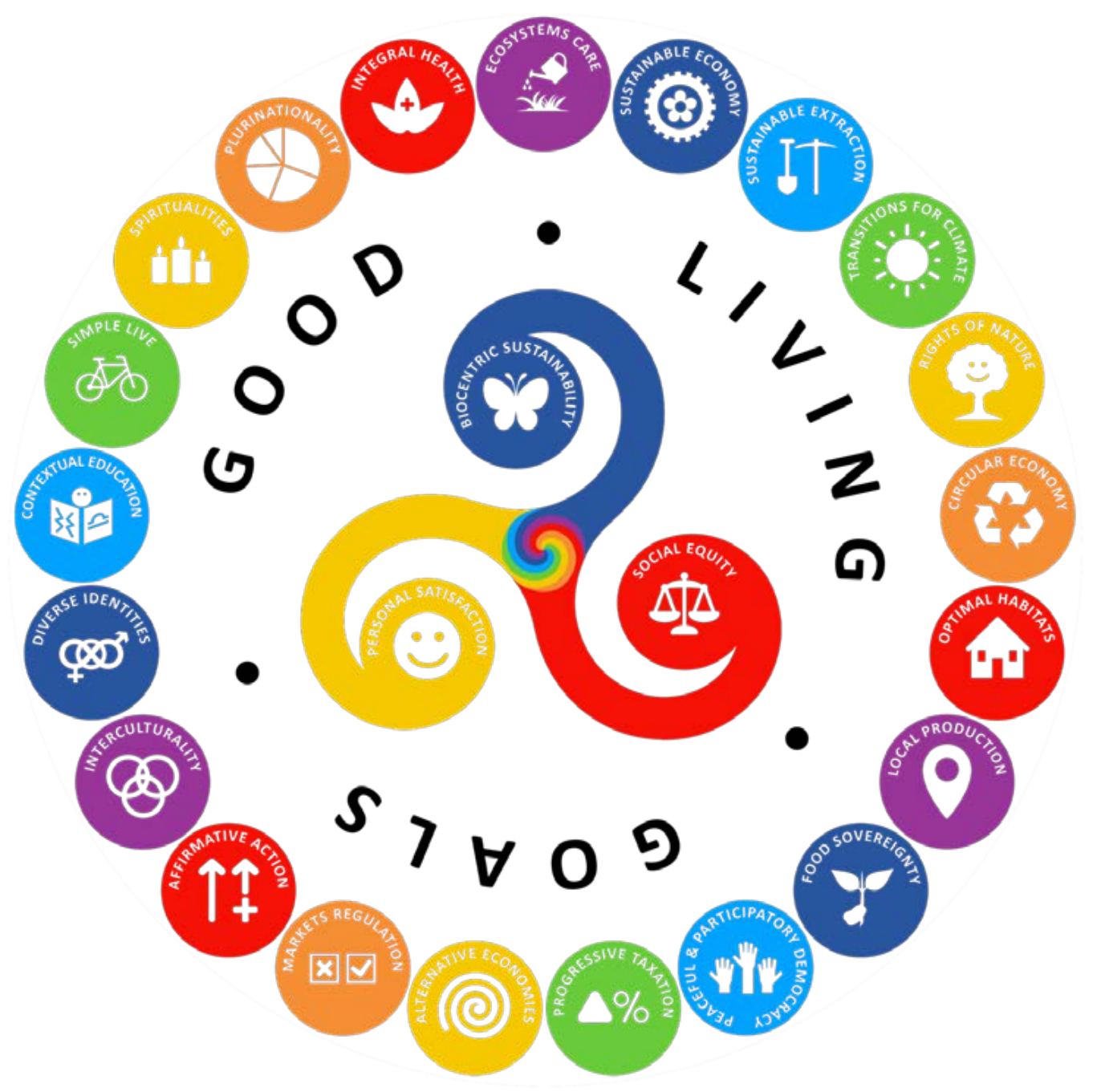

Source: Translation from Hidalgo-Capitán et al. (2019, p. 55). 
Good Living Goals $\mid 84$

\section{References}

Acosta, A. et al. (2009): Plurinacionalidad. Democracia en diversidad. Abya Yala, Quito.

Acosta, A. et al. (2011): La Naturaleza con derechos. De la filosofía a la política. Abya Yala, Quito.

Albó, X. (2011): 'Hacia el poder indígena en Ecuador, Perú y Bolivia'. In: A. C. Betancur, Movimientos indígenas en América Latina. IWGIA, Copenhague.

Brandt, W. et al. (1980): North-South: A Programme for Survival. Pan Books, London.

Chaeyoon, L. \& Putnam, R. (2010): 'Religion, Social Networks, and Life Satisfaction'. American Sociological Review 75(6): 914-33.

Cubillo-Guevara, A. P. \& Hidalgo-Capitán, A. L. (2015): 'El trans-desarrollo como manifestación de la trans-modernidad. Más allá de la subsistencia, el desarrollo y el post-desarrollo', Revista de Economía Mundial 41: 127-58.

Daly, H. E. (1996): Beyond Growth. Beacon Press, Boston, MA.

Delors, J. et al. (1996): Learning. Unesco Publishing, Paris.

Diener, E., Suh, E., Lucas, R., \& Smith, H. (1999): 'Subjective Well-Being'. Psychological Bulletin 125(2): 276-302.

Dixon, H. (2001): 'Oligopoly Theory Made Simple'. In: H. Dixon, Surfing Economics. Springer, Luxemburg.

Ellen MacArthur Foundation (2012, 2013, 2014): Towards the Circular Economy. Vols. 1, 2 \& 3. Ellen MacArthur Foundation, Coves, UK.

Fishkin, J. S. (2011): When the People Speak. OUP, Oxford, UK. 
Foro Mundial por la Soberanía Alimentaria (2001): Declaración Final del Foro Mundial por la Soberanía Alimentaria. FMSA, La Habana.

Freire, P. (1968): Pedagogy of the Oppressed. Herder \& Herder, New York, 1970.

Fujita, M. \& Thise, J. F. (2002): Economics of Agglomeration. CUP, Cambridge, UK.

García-Canclini, N. (1990): Culturas híbridas. Grijalbo, México, DF.

Girardot, J. J. (2010): 'Inteligencia territorial y transición socio-ecológica'. Trabajo 23: 15-39.

Gortz, A. (1997): Misères du présent, richesse du possible. Galilée, Paris.

Gortz, A. (2003): L’Immatériel. Galilée, Paris.

Gudynas, E. (2010): 'La senda biocéntrica'. Tabula Rasa 13: 45-71.

Hidalgo-Capitán, A. L. \& Cubillo-Guevara, A. P. (2016): Transmodernidad y transdesarrollo. El decrecimiento y el buen vivir como dos versiones análogas de un transdesarrollo transmoderno. Bonanza, Huelva, Spain.

Hidalgo-Capitán, A. L., García-Álvarez, S., Cubillo-Guevara, A. P., \& MedinaCarranco, N. (2018): Los Objetivos del Buen Vivir a escala global. Una crítica de los Objetivos de Desarrollo Sostenible y una propuesta alternativa transmoderna. Bonanza, Huelva, Spain.

Hidalgo-Capitán, A. L., García-Álvarez, S., Cubillo-Guevara, A. P., \& MedinaCarranco, N. (2019): 'Los Objetivos del Buen Vivir: una propuesta alternativa a los Objetivos de Desarrollo Sostenible', Iberoamerican Journal of Development Studies 8(1): 6-57.

Holt, M. (2002): 'It's Time to Start the Slow School Movement'. Phi Delta Kappan $84(4): 264-71$. 
Good Living Goals | 86

Honty, G. \& Gudynas, E. (2014): Cambio climático y transiciones al buen vivir. CLAES \& RedGE, Lima.

Kebir, L. \& Torre, A. (2012): Geographical Proximity and New Short Food Supply Chains. In: L. Lazzeretti (ed.), Creative Industries and Innovation in Europe. Routledge, London.

Latouche, S. (2006): Le pari de la décroissance. Fayard, Paris.

Lupien, P. (2011): 'The incorporation of indigenous concepts of plurinationality into the new constitutions of Ecuador and Bolivia'. Democratization 18(3): 774-96.

Marsden, T., Banks, J., \& Bristow, G. (2000): 'Food Supply Chain Approaches'. Sociologia Ruralis 40: 424-38.

Max-Neef, M., Elizalde, A., \& Hopenhayn, M. (1986): 'Desarrollo a escala humana'. Development Dialogue, Special Issues, 1986.

Meadows, D. H., Meadows, D. L., Randers, J., \& Behrens, W. W. (1972): The Limits to Growth. A Potomac Associate Books, Washington, DC.

Mignolo, W. (2007): La idea de América Latina. Gedisa, Barcelona, Spain.

Múnera, M. C. (2016): 'Resignificar el desarrollo en la era del postdesarrollo: propuesta hacia un 'trans-desarrollo". In: C. A. Arango, Desarrollo y territorio, pp. 17-47. Fondo Editorial de la Universidad Católica de Oriente, Río Negro, Colombia.

Oishi, S., Schimmack, U., \& Diener. E. (2012): 'Progressive Taxation and the Subjective Well-Being of Nations'. Psychological Science 23(1): 86-92.

World Health Organization, WHO (2013). WHO Traditional Medicine Strategy: 2014-2023. WHO, Hong Kong

Paredes, J. (2010): Hilando fino. Comunidad Mujeres Creando Comunidad, La Paz.

Piketty, T. (2013): Le Capital au xxie siècle. Le Seuil, Paris. 
Quijano, A. (2000): 'Colonialidad del poder y clasificación social'. Journal of World Systems Research 1(2): 342-86.

Quilligan, J. B. (2002): The Brandt Equation. Brandt 21 Forum, Philadephia, PA.

Robeyns, I. (2014): 'Having too much'. In: J. Knight \& M. Schwarzberg (eds.), NOMOS LVI: Wealth, pp. 1-44. NYU Press, New York, NY.

Rodríguez-Magda, R. M. (2004): Transmodernidad. Anthropos, Barcelona.

Rosset, P. \& Martínez, M. E. (2014): 'Soberanía Alimentaria'. Ecofronteras 18: 811 .

Savater, F. (2004): 'Laicismo'. El País 03/04/2004.

Stewart, F., Langer, A., Venugopal, R., \& Brown, G. (eds.) (2012): Affirmative Action in Plural Societies. Palgrave Macmillan, Basingstoke, UK.

Taylor, P. (1986): Respect for Nature. PUP, Princetone, NJ.

Thompson, N. (2016): Anti-Discriminatory Practice. Palgrave Macmillan, Basingstoke, UK.

Tortosa, J. M. (2009): 'Maldesarrollo como mal vivir'. América Latina en Movimiento 445: 18-21.

Walsh, C. (2009): 'Interculturalidad crítica y pedagogía de-colonial'. UMSA Revista (entre palabras), 3 .

Warnock, H. M. et al. (1978): Report of the Committee of Enquiry into the Education of Handicapped Children and Young People. Her Magestic Stationery Office, London.

Wilkinson, R. \& Pickett, K. (2009): The Spirit Level. Allen Lane, London 